\title{
PENGARUH MODEL PEMBELAJARAN DISCOVERY LEARNING DAN NUMBER HEAD TOGETHER TERHADAP AKTIVITAS, MOTIVASI DAN HASIL BELAJAR SISWA
}

\section{THE INFLUENCE OF DISCOVERY AND NUMBER HEAD TOGETHER LEARNING MODEL ON THE ACTIVITY, MOTIVATION AND STUDENT LEARNING OUTCOMES}

\author{
Soesilowaty Halim*, Didimus Tanah Boleng, P.M Labulan \\ Program Studi Pendidikan Biologi, Fakultas Keguruan dan Ilmu Pendidikan, Universitas Mulawarman \\ Jalan Gunung Kelua Samarinda. Indonesia \\ Email: soesihalim69@gmail.com
}

Diterima: 25 Juni 2018. Disetujui: 18 September 2018. Dipublikasikan: 31 Maret 2019

\begin{abstract}
Abstrak. Penelitian ini bertujuan untuk mengetahui pengaruh model pembelajaran discovery learning dan number head together terhadap aktivitas, motivasi dan hasil belajar siswa. Penelitian ini merupakan penelitian eksperimen semu (quasi experimental design). Adapun desain yang digunakan pada penelitian ini adalah pretest-posttest control group design. Populasi dalam penelitian ini adalah seluruh siswa kelas X MIPA Tahun Pelajaran 2017/2018 di SMA Negeri 3 Samarinda yang berjumlah 286 siswa, dengan sampel yang terdiri dari 3 kelas yakni X MIPA 1 sebagai kelas eksperimen 1 (dengan model discovery learning DL), kelas X MIPA 2 sebagai kelas eksperimen 2 (dengan model number head together NHT) dan kelas X MIPA 3 sebagai kelas control (dengan model konvensional). Instrument dalam penelitian ini berupa lembar observasi, angket dan soal pre-test dan post-test. Hasil penelitian menunjukkan bahwa: (1) Ada pengaruh model pembelajaran $D L$ terhadap Aktivitas Belajar siswa kelas X SMAN 3 Samarinda. Pengaruh Model $D L$ bersifat positif terhadap tingginya aktivitas belajar siswa. (2) Ada pengaruh model Pembelajaran NHT terhadap aktivitas belajar siswa kelas X SMAN 3 Samarinda. Model NHT berpengaruh positif terhadap aktivtas belajar siswa. (3) Ada pengaruh model pembelajaran $D L$ terhadap Motivasi Belajar siswa kelas X SMAN 3 Samarinda. Pengaruh Model $D L$ bersifat positif terhadap tingginya motivasi belajar siswa. (4) Ada pengaruh model Pembelajaran NHT terhadap motivasi belajar siswa kelas X SMAN 3 Samarinda. Model NHT berpengaruh positif terhadap motivasi belajar siswa. (5) Ada pengaruh model pembelajaran $D L$ terhadap Hasil Belajar siswa kelas X SMAN 3 Samarinda. Pengaruh Model $D L$ bersifat positif terhadap nilai hasil belajar siswa. (6) Ada pengaruh model Pembelajaran NHT terhadap hasil belajar siswa kelas X SMAN 3 Samarinda. Model NHT berpengaruh positif terhadap nilai hasil belajar siswa.
\end{abstract}

Kata Kunci: discovery learning, number head together, aktivitas, motivasi, hasil belajar

Abstract. This study aims to determine the influence of discovery learning and number head together on student activity, motivation and student learning outcomes. This research is a quasi-experimental study (quasi experimental design). This study is using the Pretest-Posttest Control Group Design. The population in this study were all students of class X MIPA in Academic Year 2017/2018 in SMA Negeri 3 Samarinda, totaling 286 students, with samples consisting of 3 classes namely X MIPA 1 as experimental class 1 (with Discovery Learning), class X MIPA 2 as experimental class 2 (with NHT) and class X MIPA 3 as control class (with conventional learning). The instruments in this study using the form of observation sheets, questionnaires and pre-test and post-test questions. The results of the study show that: (1) There is the influence of the discovery learning on Learning Activities of class X students of SMAN 3 Samarinda. The influence of the discovery learning is positive on the high student learning activities. (2) There is the influence of the NHT Learning model on the learning activities of class X students of SMAN 3 Samarinda. The NHT model has a positive effect on student learning activities. (3) There is the influence of the discovery learning on Learning Motivation of class $\mathrm{X}$ students of SMAN 3 Samarinda. The influence of the discovery learning is positive on the high motivation of student learning. (4) There is the influence of the NHT Learning model on the learning motivation of class X students of SMAN 3 Samarinda. The NHT model has a positive effect on student learning motivation. (5) There is the influence of the discovery learning on the Learning Outcomes of class X students of SMAN 3 Samarinda. The influence of the discovery learning is positive on the value of student learning outcomes. (6) There is the influence of the NHT Learning model on the learning outcomes of class X SMAN 3 Samarinda. The NHT model has a positive effect on the value of student learning outcomes.

Keywords: discovery learning, discovery learning, activity, motivation, learning outcomes 


\section{PENDAHULUAN}

Pembelajaran pada hakikatnya adalah usaha sadar dari seorang guru untuk membelajarkan siswanya (mengarahkan interaksi siswa dengan sumber belajar lainnya) dalam rangka mencapai tujuan yang diharapkan [1]. Tujuan proses belajar mengajar secara ideal yaitu agar semua peserta didik dapat menguasai bahan ajar secara maksimal. Namun ternyata masalah yang masih banyak diperbincangkan adalah rendahnya mutu pendidikan yang tercermin dari rendahnya rata-rata hasil belajar.

Selain itu, dalam pelaksanaan masih ada anggapan bahwa siswa dalam satu kelas mempunyai kemampuan dan cara belajar yang sama. Dengan pengajaran klasikal yang melihat sejumlah peserta didik dengan pemberian pengajaran yang sama, tentu saja tidak sejalan dengan asas bahwa anak itu secara individual berbeda-beda dalam kemampuan dasarnya, minat, kecepatan, dan lamban belajarnya.

Pembelajaran pada Kurikulum 2013 menggunakan pendekatan saintifik atau pendekatan berbasis proses keilmuan. Pendekatan saintifik dapat menggunakan beberapa strategi seperti pembelajaran kontekstual. Model pembelajaran merupakan suatu bentuk pembelajaran yang memilikinama, ciri, sintak, pengaturan, danbudayamisalnyadiscovery learning, projectbased learning, problem-based learning, inquiry learning.

SMA Negeri 3 Samarinda adalah salah satu sekolah yang mengimplementasikan Kurikulum 2013 sejak tahun pelajaran 2013-2014 bagi kelas $X$. Dalam pengimplementasiannya banyak sekali kendala yang dihadapi. Salah satunya adalah mengubah mindset guru, dari teacher centered ke student centered. Sebagai akibatnya adalah sukarnya mencapai standar Kriteria Ketuntasan Minimal (KKM) yang telah ditetapkan. Berdasarkan hasil observasi, guru menyatakan bahwa materi Protista pada mata pelajaran biologi adalah materi yang sulit dipahami siswa. Konsep materi yang didominasi objek-objek mikroskopik serta bersifat hafalan menyebabkan siswa kesulitan dalam memahami materi ini. Hal senada juga dikemukakan oleh siswa. Dari hasil observasi berupa angket yang disebar kepada siswa kelas XI pada tahun pelajaran yang sama 20172018, 85\% menyatakan materi Protista yang paling sulit dikuasai. Selain itu, keterampilan guru dalam merencanakan, melaksanakan, serta mengevaluasi pembelajaran serta karakteristik siswa yang berbeda menjadi hambatan/permasalahan sehingga nilai yang diperoleh siswa masih banyak berada di bawah KKM yang telah ditetapkan pada mata pelajaran biologi yaitu 75 . Hal ini terlihat pada hasil ulangan harian materi Protista siswa kelas X SMA Negeri 3 Samarinda Tahun Pelajaran 20162017, yang terdiri dari 239 siswa dengan persentase ketuntasan 32,22 \%. Yang tidak memenuhi KKM sebanyak $67,78 \%$.

Berdasarkan hasil wawancara dengan guru Biologi yang mengajar di kelas $\mathrm{X}$ pada tahun 2016, aktivitas dan motivasi siswa menurun menjelang berakhirnya semester karena konsentrasi siswa terbagi dengan berbagai kegiatan maupun tugas yang harus diselesaikan.Indikasi menurunnya keaktivan siswa terlihat dalam proses pembelajaran di kelas, siswa cenderung diam mendengarkan, enggan menjawab pertanyaan ataupun bertanya. Motivasi belajar akan membantu siswa memusatkan perhatian selama pembelajaran sehingga proses belajar lebih efektif. Hal ini karena siswa yang memiliki motivasi akan mengadakan respon untuk mencapai tujuan [2].

Upaya untuk mengatasi permasalahan tersebut, peneliti mencoba untuk menggunakan model pembelajaran Discovery Learning dan Number Head Together (NHT). Penggunaan Discovery Learning, ingin mengubah kondisi belajar yang pasif menjadi aktif dan kreatif. Mengubah pembelajaran yang teacher oriented ke student oriented. Merubah modus Ekspository peserta didik hanya menerima informasi secara keseluruhan dari guru ke modus Discovery peserta didik menemukan informasi sendiri [3-6]. Sedangkan model pembelajaran tipe NHT kelebihannya adalah dapat memberikan kesempatan kepada siswa untuk saling membagikan ide-ide dan memper-timbangkan jawaban yang paling tepat. Selain itu, model ini juga mendorong siswa untuk meningkatkan semangat kerja sama antara anggota kelompok dan pembelajaran ini melibatkan lebih banyak siswa dalam menelaah materi yang tercakup dalam suatu pelajaran, sehingga secara tidak langsung dapat mengecek pemahaman tiap anggota kelompok terhadap materi pelajaran tersebut [7-13].

Oleh karena itu, peneliti mencoba mengetahui pengaruh kedua model pembelajaran tersebut terhadap aktivitas, motivasi dan hasil belajar siswa pada materi Protista sehingga dapat dijadikan alternative mengatasi masalah yang terjadi. Dengan penggunaan kedua model tersebut diharapkan mampu meningkatkan aktivitas, motivasi dan hasi belajar materi Protista.

\section{METODOLOGI PENELITIAN}

Jenis penelitian ini adalah penelitian eksperimen semu (quasi experimental design). Penelitian ini tergolong penelitian komparatif dengan pendekatan eksperimen. Penelitian komparatif adalah suatu penelitian yang bersifat membedakan. Menguji hipotesis komparatif berarti menguji parameter populasi yang terbentuk perbedaan [14].

Penelitian ini bersifat quasi eksperimen. Desain ini mempunyai kelompok kontrol, namun tidak dapat berfungsi sepenuhnya untuk 
mengontrol variabel-variabel luar yang mempengaruhi pelaksanaan eksperimen [14]. Desain yang digunakan pada penelitian ini adalah Pretest-Posttest Control Group Design. Desain penelitian digambarkan pada Tabel 1 .

Tabel 1. Desain Penelitian

\begin{tabular}{cccc}
\hline Kelompok & $\begin{array}{c}\text { Pretes } \\
\text { Angket }\end{array}$ & Perlakuan & $\begin{array}{c}\text { Postes } \\
\text { Angket }\end{array}$ \\
\hline $\mathrm{R}_{1}$ & $\mathrm{Q}_{1}$ & $\mathrm{X}_{1} \mathrm{Y}_{1} \mathrm{Y}_{2}$ & $\mathrm{Q}_{2}$ \\
$\mathrm{R}_{2}$ & $\mathrm{Q}_{1}$ & $\mathrm{X}_{2} \mathrm{Y}_{1} \mathrm{Y}_{2}$ & $\mathrm{Q}_{2}$ \\
$\mathrm{R}_{3}$ & $\mathrm{Q}_{1}$ & $\mathrm{X}_{3} \mathrm{Y}_{1} \mathrm{Y}_{2}$ & $\mathrm{Q}_{3}$ \\
\hline
\end{tabular}

Keterangan:

$\mathrm{R}_{1} \quad$ : Kelompok eksperimen I

$\mathrm{R}_{2} \quad$ : Kelompok eksperimen II

$\mathrm{R}_{3} \quad$ : Kelompok kontrol

\begin{abstract}
$\mathrm{Q}_{1} \quad$ : Pretes
$\mathrm{Q}_{2} \quad$ : Postes

$\mathrm{X}_{1} \quad$ : Perlakuan pembelajaran menggunakan model Discovery Learning

X2 : Perlakuan pembelajaran menggunakan model Number Head Together

X3 : Tanpa perlakuan model pembelajaran/ model Konvensional

Y1 : Angket aktivitas belajar

Y2 : Angket motivasi belajar

Populasi dalam penelitian ini adalah seluruh siswa kelas X MIPA SMA Negeri 3 Samarinda pada semester ganjil tahun pelajaran 2017/2018, yaitu kelas X MIPA1 sampai kelas X MIPA8. Dengan jumlah 286 siswa. Terdistribusi setiap kelasnya 36 siswa.
\end{abstract}

Tabel 2. Teknik Pengumpulan Data

\begin{tabular}{lllll}
\hline \multicolumn{1}{c}{ Data } & \multicolumn{1}{c}{ Teknik } & \multicolumn{1}{c}{ Instrumen } & Responden & Analisis Data \\
\hline Aktivitas Belajar & $\begin{array}{l}\text { Mengamati } \\
\text { dengan lembar } \\
\text { observasi } \\
\text { Angket }\end{array}$ & Lembar obsrevasi & Siswa & $\begin{array}{l}\text { Deskriptif } \\
\text { Kualitatif }\end{array}$ \\
Motivasi Belajar & Angket motivasi & Siswa & $\begin{array}{l}\text { Deskriptif } \\
\text { Kualitatif }\end{array}$ \\
Hasil Belajar & Non Tes & Soal Pretest dan Postest & Siswa & $\begin{array}{l}\text { Deskriptif } \\
\text { Kuantitatif }\end{array}$ \\
Tanggapan Guru & Angket & Angket & Guru & $\begin{array}{l}\text { Deskriptif } \\
\text { Kualitatif } \\
\text { Tanggapan Siswa }\end{array}$ \\
Angket & Angket & Siswa & $\begin{array}{l}\text { Deskriptif } \\
\text { Kualitatif }\end{array}$ \\
\hline
\end{tabular}

Teknik samping yang digunakan pada penelitian ini adalah purposive sampling. Sampel diambil dengan pertimbangan, dimana dari total populasi diambil 3 kelas yang dijadikan sebagai sampel dianggap setara, ke tiga kelas ini sudah diuji kesetaraannya. Kelas X MIPA1 sebagai kelas eksperimen 1 (dengan model DL) dan X MIPA2 sebagai kelas eksperimen 2 (dengan model NHT) Sedangkan kelas X MIPA3 sebagai kelas kontrol dengan model dan metode pembelajaran Konvensional.

Untuk memperoleh data-data yang dibutuhkan dalam penelitian ini, digunakan teknik pengumpulan data seperti yang terangkum pada tabel 2.

Teknik analisis data dalam penelitian ini menggunakan statistik deskriptif dan statistik inferensial. Statistic deskriptif digunakan untuk mengungkapkan skor dan mengkategorikan variabel terikat yaitu aktivitas, motivasi dan hasil belajar. Sedangkan statistic inferensial digunakan untuk menguji hipotesis penelitian, yakni menggunakan uji Anacova menggunakan SPSS Versi 22.0

\section{HASIL PENELITIAN DAN PEMBAHASAN}

Uji hipotesis pengaruh model pembelajaran terhadap aktivitas belajar dengan mengunakan SPSS versi 22, diperoleh hasil pada table 3 .

Tabel 3. Uji Anacova Model Pembelajaran Terhadap Aktivitas Belajar Siswa

\begin{tabular}{lcrrrr}
\hline Source & $\begin{array}{l}\text { Type III } \\
\text { Sum of } \\
\text { Squares }\end{array}$ & df & $\begin{array}{c}\text { Mean } \\
\text { Square }\end{array}$ & $\mathrm{F}_{\text {hitung }}$ & Sig. \\
\hline $\begin{array}{l}\text { Correcte } \\
\text { d Model }\end{array}$ & $110.019^{\mathrm{a}}$ & 2 & 55.009 & 7.850 & .001 \\
Intercept & 24420.148 & 1 & 24420.1 & 3484.6 & .000 \\
Model & 110.019 & 2 & 55.009 & 7.850 & .001 \\
Error & 735.833 & 105 & 7.008 & & \\
Total & 25266.000 & 108 & & & \\
a. $R$ Squared $=.130$ (Adjusted $R$ Squared $=.113)$ & \\
\hline
\end{tabular}

Pada tabel 3, diperoleh nilai Fhitung = 7,850 dan nilai sig. $0,001<0.05$, berarti ada perbedaan hasil aktivitas belajar siswa yang diberi 
pembelajaran model DL, model NHT dengan siswa yang diberi pembelajaran konvensional.

Berdasarkan hasil uji lanjut LSD untuk perbandingan aktivitas belajar model DL terhadap aktivitas belajar model NHT memiliki nilai sig. $(0.859)>0.05$, berarti tidak terdapat perbedaan antara aktivitas belajar model DL dengan aktivitas belajar model NHT. Model DL dan NHT mempunyai pengaruh yang sama terhadap aktivitas belajar siswa. Hal ini terjadi karena baik model DL maupun NHT memiliki kelebihan yang sama dalam membangkitkan aktivitas belajar siswa. Selanjutnya perbandingan aktivitas belajar model DL dengan aktivitas belajar konvensional diperoleh nilai sig $(0.001)<0.05$ berarti ada perbedaan yang nyata antara kedua aktivitas belajar tersebut. Kemudian perbandingan antar aktivitas belajar model NHT terhadap aktivitas belajar konvensional diperoleh nilai sig. $(0.001)<0.05$ berarti ada perbedaan yang nyata antar aktivitas belajar keduanya.

Model pembelajaran kooperatif learning tipe NHT ini memang memiliki kelebihan yang dapat melatih siswa berinteraksi dengan siswa lain,sehingga semua siswa aktif dalam proses pembelajaran serta menimbulkan rasa tanggung jawab sesama kelompok sehingga dapat meningkatkan penguasaan akademik siswa. Hal senada dikatakan oleh Fathurrohman [2] bahwa model NHT dapat meningkatkan keterampilan. Keterampilan yang dimaksud antara lain berbagi tugas, aktif bertanya, menghargai pendapat orang lain, mau menjelaskan ide atau pendapat, bekerja dalam kelompok dan sebagainya

Uji hipotesis pengaruh model pembelajaran terhadap motivasi belajar dengan mengunakan SPSS versi 22, diperoleh hasil pada table 4 .

Tabel 4. Uji Anacova Model Pembelajaran Terhadap Motivasi Belajar Siswa

\begin{tabular}{lcrrrr}
\hline Source & $\begin{array}{l}\text { Type III } \\
\text { Sum of } \\
\text { Squares }\end{array}$ & df & $\begin{array}{c}\text { Mean } \\
\text { Square }\end{array}$ & $\mathrm{F}_{\text {hitung }}$ & Sig. \\
\hline Corrected & 13721.147 & 3 & 4573.72 & 54.632 & .000 \\
Model & a & & & & \\
Intercept & 3156.073 & 1 & 3156.07 & 37.699 & .000 \\
Model & 8618.795 & 1 & 8618.79 & 102.95 & .000 \\
Error & 5390.274 & 2 & 2695.14 & 32.193 & .000 \\
Total & 8706.733 & 104 & 83.719 & & \\
a. $R$ Squared $=.612$ (Adjusted $R$ Squared $=.601)$ \\
\hline \multicolumn{7}{c}{ Squared }
\end{tabular}

Pada penelitian ini nilai corrected model untuk Fhitung $=54,632>$ Ftabel $=2,692$ dan nilai sig $0.000<0.05$, nilai ini berarti variabel-variabel bebas (model DL, model NHT, Konvensional dan motivasi belajar awal) secara bersama-sama berpengaruh terhadap variabel terikat (motivasi belajar).
Untuk variabel model pembelajaran, nilai Fhitung $=32,193>$ Ftabel $=3,083$ dan nilai sig $0,000<0.05 \quad(\alpha)$ maka variabel model pembelajaran berpengaruh terhadap motivasi belajar artinya ada perbedaan motivasi belajar siswa dengan perlakuan model DL, model NHT dan siswa dengan pembelajaran konvensional. Jadi, motivasi belajar awal/sebelum perlakuan berpengaruh terhadap motivasi belajar sesudah perlakuan, baik motivasi belajar rendah, motivasi belajar sedang maupun motivasi belajar tinggi.

Berdasarkan hasil uji lanjut pengaruh perlakuan model pembelajaran terhadap motivasi belajar menjelaskan bahwa terdapat perbedaan nyata antara hasil motivasi belajar kelas DL dengan hasil motivasi belajar konvensional. Ini berarti pembelajaran model DL menhasilkan motivasi belajar yang lebih baik dari pembelajaran konvensional. Hal itu terjadi juga pada pembelajaran model NHT, lebih baik motivasi belajarnya dibanding motivasi belajar pada pembelajaran konvensional. Ini terlihat dari hasil motivasi belajar kelas NHT dengan kelas konvensional juga berbeda nyata, sedangkan hasil motivasi belajar kelas DL dengan NHT tidak terdapat perbedaan yang nyata, maka kedua model ini sama baiknya dalam member pengaruh pada motivasi belajar siswa.

Uji hipotesis pengaruh model pembelajaran terhadap hasil belajar kognitif dengan mengunakan SPSS versi 22, diperoleh hasil pada table 5 .

Tabel 5. Uji Anacova Model Pembelajaran Terhadap Hasil Belajar Kognitif

\begin{tabular}{lcrrrr}
\hline Source & $\begin{array}{l}\text { Type III } \\
\text { Sum of } \\
\text { Squares }\end{array}$ & df & $\begin{array}{c}\text { Mean } \\
\text { Square }\end{array}$ & $F_{\text {hitung }}$ & Sig. \\
\hline Correcte & $2047.645^{\mathrm{a}}$ & 3 & 682.548 & 17.743 & .000 \\
d Model & & & & & \\
Intercept & 132834.9 & 1 & 132834.95 & 3453.15 & .000 \\
Model & 1060.460 & 1 & 1060.46 & 27.567 & .000 \\
Error & 1605.949 & 2 & 802.974 & 20.874 & .000 \\
Total & 4000.651 & 104 & 38.468 & & \\
a. $R$ Squared $=.152$ (Adjusted $R$ Squared $=.127)$ & \\
\hline
\end{tabular}

Pada penelitian ini nilai corrected model untuk Fhitung $=17.743>$ Ftabel $=2,692$ dan nilai sig $0.000<0.05$, berarti variabel-variabel bebas (model DL, model NHT, konvensional dan hasil pretest) secara bersama-sama berpengaruh terhadap variabel terikat (hasil belajar).

Untuk variabel model pembelajaran nilai Fhitung $=20,874>$ Ftabel $=3,083$ dan nilai sig $0,000<0.05 \quad(\alpha)$ maka variabel model pembelajaran berpengaruh terhadap hasil belajar artinya ada perbedaan hasil belajar siswa yang diberi pembelajaran dengan model DL, model NHT 
dan dengan siswa yang diberi pembelajaran konvensional. Artinya hasil belajar pretest berpengaruh terhadap hasil belajar posttest.

Berdasarkan hasil uji lanjut LSD untuk hasil belajar konvensional terhadap hasil belajar model DL, ada perbedaan yang nyata antara kedua model pembelajaran pada hasil belajarnya, artinya model DL dan Konvensional memiliki pengaruh yang berbeda terhadap hasil belajar siswa. Demikian juga hasil belajar model konvensional terhadap hasil belajar model NHT, memiliki pengaruh yang berbeda terhadap hasil belajar siswa. Sedangkan perbandingan antara hasil belajar model DL terhadap hasil belajar model NHT, tidak terdapat perbedaan antara hasil belajar model DL dengan hasil belajar model NHT, maka kedua model pembelajaran memberi pengaruh yang sama terhadap hasil belajar siswa.

Alasan Model Discovery dan NHT berpengaruh signifikan terhadap Motivasi belajar. Model Discovery dan NHT mengajarkan siswa belajar secara langsung di laboratorium dengan contoh-contoh nyata dan tidak hanya terpaku oleh materi yang disampaikan oleh guru. Siswa dilatih untuk mencari informasi sesuai tema materi untuk membantu saat kegiatan penemuan.Mencari informasi dilakukan dengan menggunkan persepsi langsung dengan meberikan petunjuk-petunjuk di lingkungan sekitar, ketimbang menggunakan citra retinal sebagai titik awal pemprosesan perseptual [15]. Tujuan yang dihasilkan dari pendekatan persepsi langsung ini bukanlah suatu representasi internal lingkungan melainkan suatu kesadaran untuk berinteraksi lingkungan, sehingga membuat siswamampu mengenali Kingdom Protista.

Motivasi belajar siswa berhubungan dengan karakteristik, mental, serta emosional. Motivasi merupakan energi mental yang dimiliki seseorang agar menjadi pribadi yang lebih kuat ataupun lemah karena alasan tertentu [16]. Faktor internal (pengalaman pribadi) dapat menjadikan pribadi yang berprestasi. Faktor eksternal dari familiy, teman, ataupun lingkungan belajar akan mendukung penyebab dari pencapaian prestasi. Aktivitas belajar berupa rangsangan aktivitas otak untuk mengaktifkan sel-sel saraf atau neuron [17]. Rangsangan pembelajaran berupa motivasi dan model pembelajaran yang diterapkan.Motivasi dengan keinginan yang tinggi pada siswaakan mendorong semangat dalam proses pembelajaran serta berlatih sesuai keahliannya.

Indikator adanya hasrat dan keinginan pada di siswaakan berprestasi dan berhasil jika sesuai dengan keahliannya. Motivasi setiap siswa yang mempunyai keahlian dalam mencapai keberhasilan dan prestasi bertujuan untuk unggul berkompetisi [18]. Siswa yang memilki motivasi berprestasi seringkali tangkas serta belajar secara mandiri [19]. Siswa bercita-cita sukes di masa yang akan dating sehingga motivasi pada dirinya semakin tinggi.

Motivasi eksternal pada Indikator kegiatan yang menarik siswa.Siswa memerlukan kegiatan yang menarik dan seru dalam kegiatan pembelajaran untuk memacu motivasi. Peningkatan prestasi akademik serta peningkatan motivasi berprestasi pada mahasiswa S1 Pendidikan geografi di Universitas Negeri Malang di pengaruhi faktor dari dalam (internal) dan faktor dari luar (ekternal) siswa [18]. Faktor internal terdiri dari motivasi dan minat. Rasa perhatian, rasa ketertarikan, dan keinginan lebih dari dalam diri seseorang terhadap suatu persoalan. Sedangkan faktor eksternal terdiri dari support family, pergaulan (lingkungan), dan sarana prasarana belajar.

Hasrat dalam proses pembelajaran ditandai dengan aktif (keatifan) siswa bertanya ketika guru diberi kesempatan. Peserta didi diberi kesempatan bertanya, menyanggah, menjawab, dan diskusi dalam proses percobaan ataupun presentasi. Kesempatan tersebut diberikan apabila terdapat persoalan atau hal-hal yang dianggap siswa kurang paham sesuai dengan materi yang disampaikan, baik dengan guru ataupun siswa. Ketika siswa bertanya, guru tidak langsung menjawab pertanyaan siswa tetapi memberi kesempatan siswa yang lain untuk menanggapi penanya. Kegiatan seperti ini menjadikan kegiatan diskusi lebih bermakna karena informasi yang diperoleh semakin banyak dan optimal dan menambah wawasan antara siswa dan guru. Otak memiliki informasi yang diserap secara cepat dengan cara keingintahuan alamiah yang dilakukan siswa [20]. Berjalannya diskusi secara maksimal akan meningakatkan motivasi siswa guna semakin berprestasi. Motivasi berprestasi adalah keinginan seseorang untuk mencapai tujuan dengan tingkatan maksimal (tertinggi) [21].

Langkah Discovery Learning dilakukan oleh siswa yaitu langkah pencarian data, pengolahan dan pembuktian. Langkah tersebut lebih banyak dilakukan diluar kelas atau di lapangan. Karena dengan turun langsung di lapangan maka data yang didapatkan menjadi lebihnya. Bentuk aktifitas siswa dalam pembelajaran di lapangan adalah pengambilan data dalam bentuk wawancara. Kegiatan yang membuat siswa berada di lapangan mengakibatkan siswa merasakan langsung pembelajaran bukan hanya sekedar konsep akan tetapi aplikasinya secara nyata. Pemahaman konsep menjadi lebih dalam ketika siswa benar-benar mengalaminya di lapangan. Pengalaman tersebut yang sulit dilupakan oleh siswa. Pendapat tersebut didukung oleh Hosnan yang mengutarakan pembelajaran aktif siswa dengan menemukan sendiri, menyelidiki sendiri maka hasil yang diperoleh akan setia dan tahan lama dalam ingatan siswa[22]. 
Konsep dan pengalaman yang tidak mudah terlupa tersebut akan mempengaruhi hasil belajar siswa.

Berdasarkan catatan lapangan dan teori yang dikemukakan, faktor yang berpengaruh pada hasil belajar yang terdapat pada kelas eksperimen adalah konsentrasi belajar. Guru dalam perlakuan hanya memaparkan materi pokok dalam waktu singkat sehingga konsentrasi siswa masih penuh. Pemaparan materi yang singkat tersebut dapat meningkatkan daya tangkap siswa dan meminimalisir ganggunan dalam pembelajaran. Menurut Rooijakkers kekuatan perhatian siswa adalah tiga puluh menit setelah itu tingkat perhatian akan menurun [16]. Selain alasan tersebut menurut sintaks model pembelajaran siswa lebih banyak untuk mencari dan mengembangkan hasil yang didapat di lapangan, dengan demikian siswa akan aktif dalam proses pembelajaran.

Penyerapan materi pelajaran juga dapat diterima dengan maksimal apabila siswa dilibatkan secara aktif.Bentuk perpaduan model NHT dan Discovery Learning tersebut membuat siswa aktif dalam dalam pembelajaran melalui langkah berfikir bersama, mencari dan mengolah data.pembelajaran dengan siswa aktif akan menjadikan pengolahan bahan ajar juga semakin baik yang dapat berujung dengan hasil belajar yang baik pula. Pendapat tersebut diperkuat oleh Dimyati apabila siswa aktif maka pengolahan bahan ajar juga semakin baik [16].

\section{KESIMPULAN DAN SARAN}

Kesimpulan yang dapat diambil dari paparan pembahasan tersebut adalah:

1. Ada pengaruh model pembelajaran $D L$ terhadap Aktivitas Belajar siswa kelas $\mathrm{X}$ SMAN 3 Samarinda. Pengaruh Model $D L$ bersifat positif terhadap tingginya aktivitas belajar siswa.

2. Ada pengaruh model Pembelajaran NHT terhadap aktivitas belajar siswa kelas X SMAN 3 Samarinda. Model NHT berpengaruh positif terhadap aktivtas belajar siswa.

3. Ada pengaruh model pembelajaran $D L$ terhadap Motivasi Belajar siswa kelas X SMAN 3 Samarinda. Pengaruh Model $D L$ bersifat positif terhadap tingginya motivasi belajar siswa.

4. Ada pengaruh model Pembelajaran NHT terhadap motivasi belajar siswa kelas X SMAN 3 Samarinda. Model NHT berpengaruh positif terhadap motivasi belajar siswa.

5. Ada pengaruh model pembelajaran $D L$ terhadap Hasil Belajar siswa kelas $\mathrm{X}$ SMAN 3 Samarinda. Pengaruh Model $D L$ bersifat positif terhadap nilai hasil belajar siswa.

6. Ada pengaruh model Pembelajaran NHT terhadap hasil belajar siswa kelas X SMAN 3 Samarinda. Model NHT berpengaruh positif terhadap nilai hasil belajar siswa.
Berdasarkan hasil penelitian yang telah dilakukan, maka saran-saran yang dapat diberikan oleh penulis adalah:

1. Bagi guru, dalam melaksanakan proses belajar mengajar guru harus lebih cermat dalam memilih model pembelajaran yang tepat yang sesuai dengan karakteristik materi pelajaran. Dengan penggunaan model pembelajaran dalam proses belajar mengajar sangat berpengaruh dalam pencapaian ketuntasan hasil belajar.

2. Bagi sekolah, hasil penelitian ini dapat memotivasi guru untuk meningkatkan kemampuan dan memperbaiki proses pembelajaran agar tujuan pendidikan dapat tercapai.

3. Bagi peneliti selanjutnya supaya dapat mengembangkan penelitian ini dengan variasi metode atau pokok bahasan yang lain.

\section{DAFTAR PUSTAKA}

[1] Trianto. 2010. Mendesain Model Pembelajaran Inovatif Progresif. Jakarta. Kencana.

[2] Fathurrohman, M. 2015. Model-Model Pembelajaran Inovatif. Jakarta. Ar-Ruzz Media.

[3] Raksun, A. (2009). Implementasi Pembelajaran Kooperatif untuk Meningkatkan Motivasi Dan Hasil Belajar Mahasiswa Program Studi Pendidikan Fisika FKIP Universitas Mataram Pada mata kuliah Biologi Dasar. Jurnal pijar MIPA, 4(1).

[4] Ishak, M., Jekti, D. S. D., \& Sridana, N. (2017). Pengaruh Penerapan Pendekatan Saintifik Menggunakan Model Pembelajaran Discovery Dan Kooperatif Tipe Stad Terhadap Kemampuan Berpikir Kreatif Peserta Didik SDN 13 Ampenan. Jurnal Pijar Mipa, 12(1).

[5] Andayani, Y., Hadisaputra, S., \& Hasnawati, H. (2018, September). Analysis of the Level of Conceptual Understanding. In Journal of Physics: Conference Series (Vol. 1095, No. 1, p. 012045). IOP Publishing.

[6] Zakrah, Z., Lestari, N., \& Kusmiyati, K. (2015). Pengaruh strategi pembelajaran discovery terhadap kemampuan berpikir kritis siswa pada mata pelajaran IPA kelas VIII di SMPN 3 Gunungsari tahun ajaran 2014/2015. Jurnal pijar MIPA, 10(2).

[7] Ramandha, M. E. P., Andayani, Y., \& Hadisaputra, S. (2018, October). An analysis of critical thinking skills among students studying chemistry using guided inquiry models. In AIP Conference Proceedings (Vol. 2021, No. 1, p. 080007). AIP Publishing.

[8] Bayuaji, P., Hikmawati, H., \& Rahayu, S. (2017). Pengaruh Model Pembelajaran 
Kooperatif Tipe Student Facilitator And Explaining (Sfae) Dengan Pendekatan Saintifik Terhadap Hasil Belajar Fisika. Jurnal Pijar Mipa, 12(1).

[9] Azizah, N. (2016). Pengembangan Lks Dan Penerapannya Dalam Pembelajaran Kooperatif Tipe STAD Untuk Meningkatkan Aktivitas dan Hasil Belajar Kimia Siswa. Jurnal Pijar Mipa, 11(1).

[10] Susanto, J. (2012). Pengembangan Perangkat Pembelajaran Berbasis Lesson Study dengan Kooperatif Tipe Numbered Heads Together untuk Meningkatkan Aktivitas dan Hasil Belajar IPA di SD. Journal of Primary Education, 1(2).

[11] Mulyana, M. A., Hanifah, N., \& Jayadinata, A. K. (2016). Penerapan model kooperatif tipe numbered heads together (NHT) untuk meningkatkan hasil belajar siswa pada materi kenampakan alam dan sosial budaya. Jurnal Pena Ilmiah, 1(1), 331-340.

[12] Daud, F., \& Fausan, M. M. (2013). Penerapan Model Pembelajaran Kooperatif Tipe Numbered Head Together untuk Meningkatkan Aktivitas dan Hasil Belajar pada Konsep Ekosistem bagi Siswa Kelas VII. A, SMPN 5 Takalar. CHEMICA, 12(1), 40-46.

[13] Hasanah, M. (2015). Perbedaan hasil belajar ipa biologi menggunakan model pembelajaran kooperatif tipe numbered heads together (NHT) dengan think pair share (TPS) pada siswa kelas VIII SMPN 13
Mataram Tahun Ajaran 2015/2016. Biota, 8(2), 211-225.

[14] Sugiyono. 2016. Metode Penelitian dan Pengembangan. Bandung. CV. Alfabeta.

[15] Ling. Jonathan, dkk. 2012. Psikologi Kognitif. Jakarta: Penerbit Erlangga.

[16] Dimyati dan Mudjiono. 2006. Belajar dan Pembelajaran. Jakarta: Rineka Cipta.

[17] Utomo, D. H. (2016, November). Brain Based Learning: Effects Model A-Car In Critical Thinking Skills. In lst International Cohference on Geography and Education (ICGE 2016). Atlantis Press.

[18] Retnowati, D. R., Fatchan, A., \& Astina, I. K. (2016). Prestasi akademik dan motivasi berprestasi mahasiswa $\mathrm{S} 1$ pendidikan geografi universitas negeri malang. Jurnal Pendidikan: Teori, Penelitian, dan Pengembangan, 1(3), 521-525.

[19] Klein, S. B.,1982. "Achievement Motivation" dalam Motivation Bioscial Approachches. New York: Mc Graw-Hill Book Company.

[20] Jensen, Eric. 2011. Pemelajaran Berbasis Otak. Jakarta: Indeks

[21] Lutfiyah, Z., Utaya, S., \& Susilo, S. (2016). Hubungan antara Minat Menjadi Guru dengan Prestasi Belajar Mahasiswa. Jurnal Pendidikan Geografi, 21(2).

[22] Hosnan M. Dr. 2014. Pendekatan Saintifik dan Kontekstual. Jakarta . Ghalia 